\title{
A Hot Dynamic Seal Rig for Measuring Hypersonic Engine Seal Durability and Flow Performance
}

Jeffrey H. Miller

Sverdrup Technology, Inc.

Lewis Research Center Group

Brook Park, Ohio

Bruce M. Steinetz

National Aeronautics and Space Administration

Lewis Research Center

Cleveland, Ohio

Paul J. Sirocky

Sverdrup Technology, Inc.

Lewis Research Center Group

Brook Park, Ohio

and

Lawrence A. Kren

Case Western Reserve University

Cleveland, Ohio

Prepared for the

34th Structures, Structural Dynamics, and Materials Conference cosponsored by the AIAA, ASME, AHS, and ASC

La Jolla, California, April 19-21, 1993

\section{N/SN}




\title{
A HOT DYNAMIC SEAL RIG FOR MEASURING HYPERSONIC ENGINE SEAL DURABIIITY AND FLOW PERFORMANCE
}

\author{
Jeffrey H. Miller* \\ Sverdrup Technology, Inc. \\ Lewis Research Center Group \\ Brook Park, Ohio 44142 \\ Bruce M. Steinetz ${ }^{*}$ \\ National Aeronautics and Space Administration \\ Lewis Research Center \\ Cleveland, Ohio 44135 \\ Paul J. Sirocky* \\ Sverdrup Technology, Inc. \\ Lewis Research Center Group \\ Brook Park, Ohio 44142 \\ Lawrence A. Kren ${ }^{* *}$ \\ Case Western Reserve University \\ Cleveland, Ohio 44106
}

\begin{abstract}
A test fixture for measuring the dynamic performance of candidate high-temperature engine seal concepts has been installed at NASA Lewis Research Center. The test fixture has been designed to evaluate seal concepts under development for advanced hypersonic engines, such as those being considered for the National Aerospace Plane (NASP). The fixture can measure dynamic seal leakage performance from room temperature up to $840^{\circ} \mathrm{C}(1550 \mathrm{~F})$ and air pressure differentials up to $690 \mathrm{kPa}$ (100 psi). Performance of the seals can be measured while sealing against flat or distorted walls. In the fixture two seals are preloaded against the sides of a $30 \mathrm{~cm}(1 \mathrm{ft})$ long saber that slides transverse to the axis of the seals, simulating the scrubbing motion anticipated in these engines. This report covers the capabilities of this test fixture along with preliminary data showing the dependence of seal leakage performance on high temperature cycling.
\end{abstract}

\section{Introduction}

Seal design requirements of advanced propulsion systems, including hypersonic engines being considered for the National Aerospace Plane and advanced 2-dimensional, vectored-thrust turbojet fighter engines are severe [1]. The simultaneous requirements to operate hot while sealing ramjet combustion temperature gases of greater than $2400^{\circ} \mathrm{C}\left(4400^{\circ} \mathrm{F}\right)$ with minimal coolant requires advanced design concepts combined with high temperature materials technology. The performance of these key mechanical components must be evaluated prior to costly engine testing. This requires advanced test techniques which will be described in this paper.

Seal concepts being developed for the National Aerospace Plane (Fig. 1) engine are required to seal the many linear feet of gaps between the movable engine panels and the stationary engine sidewalls or splitter walls (Fig. 2). These paneledge seals must prevent the extremely hot, pressurized flow-path gases from escaping past the movable engine panels.

Preliminary estimates of the seal design criteria are listed in [1]. Those criteria related to the design of this test fixture are repeated below:

1. Minimize seal leakage rates. Early industry estimates have indicated a tentative leakage rate of $6 \times 10^{-3} \mathrm{~kg} / \mathrm{m}-\mathrm{s}$ $\left(4 \times 10^{-3} \mathrm{lb} / \mathrm{ft}-\mathrm{sec}\right)$ of seal.

2. Operate at temperatures of up to 649$1090^{\circ} \mathrm{C}(1200-2000 \%)$ while minimizing engine seal coolant requirements.

3. Conform to and seal against distorted adjacent sidewalls. The distortion can be as great as $4 \mathrm{~mm}$ over a $460 \mathrm{~mm}$ span ( 0.15 in over an 18 in span) - or approximately $0.010 \mathrm{~mm}$ deflection per

- Research Engineer, member ALAA

"Resident Research Associate

Copyright 1993 by the American Institute of Aeronautics and Astronautics, Inc. No copyright is asserted in the United States under Title 17, U.S. Code. The U.S. Government has a royalty-free license to exercise all rights under the copyright claimed herein for Governmental purposes.

All other rights are reserved by the copyright owner. 
millimeter of span.

4. Sustain minimal sliding damage over engine life (estimated sliding distance is $120 \mathrm{~m}$ $(400 \mathrm{ft}))$

5. Maintain material stability in the chemically hostile air, hydrogen, and steam engine environment.

\section{Previous Work}

NASA Lewis developed a high temperature static test fixture [2] to measure seal leakage rates under engine-simulated gas temperatures (up to $815^{\circ} \mathrm{C}$ $\left(1500{ }^{\circ} \mathrm{F}\right)$ ) and pressures (up to $690 \mathrm{kPa}(100 \mathrm{psi})$ ). This test fixture was used to select amongst four candidate seals those seals having leakage flow rates near or below the flow goal. Leakage tests revealed that the ceramic wafer seal and braided rope seal structures shown in Fig. 3 had relatively low leakage rates [3] and were able to conform to and seal the distorted sidewalls.

Cooperative tests performed by Pratt \& Whitney (P\&W) and NASA Lewis used a simple seal scrubbing fixture to evaluate the relative durability performance of competing braided rope seal architectures and materials [4]. In these tests, seals were preloaded and scrubbed against an articulating rub plate in a furnace operating at $700^{\circ} \mathrm{C}\left(1300^{\circ} \mathrm{F}\right)$. Long term durability benefits of hybrid (ceramic core/metal sheath) seals were demonstrated over the all-ceramic seal designs. These scrubbing tests combined with pre- and post-leakage flow measurements identified seal design features necessary for good durability and leakage. From these tests a matrix of seal architectures was developed for subsequent testing in the current high temperature dynamic seal test rig.

\section{Seal Rig Design Criteria and Objectives}

A test fixture has been installed to address the following important engine seal development issues:

1. Quantify the change in seal leakage flow rates and evaluate seal durability as a function of simulated engine cycles, at temperatures up to $815^{\circ} \mathrm{C}\left(1500^{\circ} \mathrm{F}\right)$ and pressures up to $690 \mathrm{kPa}$ (100 psi).

2. Evaluate seal leakage performance as a function of sealed gap dimension and applied preload. Identify limits of gap size and applied preload to prevent seal roll-out under the transverse sliding motion.

3. Measure the change in seal leakage between sealing against flat and distorted sidewalls.

4. Assess dependence of seal leakage on seal movement in the seal channel caused by seal-sidewall interactions.

5. Establish seal design guidelines identifying seal architecture, material, and installation techniques required for the best balance of low leakage durable seal performance.

\section{Test Fixture Description}

A primary consideration in designing the test fixture was to simulate the scrubbing motion the seals will experience in the actual engine. This is necessary for examining seal wear mechanisms and conditions leading to seal roll-out. In the engine, the seals will be scrubbed transverse to their long axes. In the test rig two seals are held in intimate contact with an articulating saber as shown in Fig. 4. The saber moves vertically through a $5 \mathrm{~cm} \mathrm{(2}$ in) stroke. Sealing both sides of the saber with the candidate test seals virtually eliminates the need for other supporting seals that must operate at the full operating temperature.

\section{End-Leakage Control}

Unlike circular seals, linear seals unavoidably have two ends. Treatment of the ends is critical to obtaining accurate measurement of the seal's leakage performance. Two steps were taken to virtually eliminate end leakage in the test rig. To seal the ends of the articulating saber, rub blocks made of Inconel X-750 material are employed. These rub blocks are machined flat and parallel and rub against both ends of the articulating saber. They are preloaded against the ends of the saber through pneumatically-actuated, hermetically-sealed bellows axial preloaders (Fig. 4), developed in [2]. The rub blocks were machined to nominal dimensions and hand-lapped in place for a precise fit with their mating rub-block cavities. This approach minimizes leakage past the rub-blocks.

Another feature controlling seal end-leakage, demonstrated in previous rig designs [2], is the technique of "building-in" the ends of the seal into the test rig. The seal test zone and saber are nominally $30 \mathrm{~cm}$ (12 in) long. The seals extend a few centimeters beyond the test zone on both ends. 
In the ends, there are no gaps that the seals must seal. The face of the seal, rig and side of the rub block all lie in the same plane. The seal is firmly preloaded (with special end loaders) laterally against the side of the rub block virtually eliminating leakage in this region. The leakage follows the path of least resistance which is the center $30 \mathrm{~cm}$ (1 ft) test zone (Fig. 4). If there is any trace leakage from the end cavities, its effect is reduced by testing $30 \mathrm{~cm}(1 \mathrm{ft})$ lengths of seal and calculating an average leakage rate in terms of leakage rate per unit seal length.

\section{Rig Heating}

Metered, pressurized air is supplied to a plenum machined into the rig base upstream of the seal (Fig. 4). In-line electric resistance air heaters are threaded into the base. Hot, pressurized air exhausting from the heaters flows through the mesh heat exchanger to the seals. A maximum of four air heaters can be attached to the rig with each delivering $0.009 \mathrm{~kg} / \mathrm{s}(0.02 \mathrm{lb} / \mathrm{s})$ of air at temperatures up to $815^{\circ} \mathrm{C}\left(1500^{\circ} \mathrm{F}\right)$ and pressures up to $690 \mathrm{kPa}$ (100 psi). Each heater is controlled by a digital controller with temperature feedback.

The mesh heat exchanger serves two purposes. First, the mesh diffuses the incoming air to the full length of the seals. Second, under low flow conditions, the thermal mass of the heat exchanger is used to boost the air heater exhaust temperature by several hundred degrees. This allows the air heaters to run cooler thereby extending their life.

High watt-density conduction heaters are strapped to the top and bottom of the test rig. Four digitally controlled $3.5 \mathrm{~kW}$ heaters are used to heat the rig to the desired test temperature. A rampsoak profile is followed that prevents the surface heater temperatures from exceeding the rig bulk temperature by more than $200^{\circ} \mathrm{C}\left(400^{\circ} \mathrm{F}\right)$. The test fixture is heated to $815^{\circ} \mathrm{C}(1500 \mathrm{~F})$ in $6.5 \mathrm{hrs}$. Due to the efficiency of thermal-conduction, these surface heaters supply most of the heat to the rig during heat-up. Employing surface heaters on the top and bottom reduce the thermal gradients and any unnecessary thermal distortions through the $15 \mathrm{~cm}$ (6 in) high test fixture.

To achieve the high test temperatures, the test rig is insulated with a high temperature capability, low conductivity board insulation. At least $5 \mathrm{~cm}$ ( 2 in) of alumina insulating board is fitted closely around the outside of the rig.

\section{$\underline{\text { Saber Actuation }}$}

The saber moves vertically between the two test seals. The saber is guided by a set of linear bearings that maintain precise alignment to the seals. The bearings have a high preload to provide the necessary stiffness and prevent any out of plane or sideways motion of the saber.

The saber articulation system is driven by a 2.2 $\mathrm{kW}(3 \mathrm{hp}$ ) variable-speed DC motor. This motor was chosen for its exceptional low speed torque. An external blower permits very slow operation without overheating. The motor drives through a 100:1 double reduction gearbox. A slip clutch is mounted between the gearbox and crank to ensure the torque does not exceed a user selected value, in the event something becomes jammed. An eccentric crank provides the desired reciprocal motion.

A connecting rod connects the crankshaft to the saber through the linear-bearing carriage assembly. A stroke of $5 \mathrm{~cm}$ (2 in) was selected for these initial tests. The average linear saber speed is adjustable from 0 to $5 \mathrm{~cm} / \mathrm{s}$ ( 0 to $2 \mathrm{in} / \mathrm{sec}$ ). Tests will be performed at $2.5 \mathrm{~cm} / \mathrm{s}$ ( 1 in $/ \mathrm{sec})$ to simulate engine seal sliding speeds. The position of the saber is measured with a linear variable differential transformer (LVDT). A cycle counter is mounted on the idler end of the crank shaft.

\section{Seal Drag Measurement}

Load cells are mounted in the saber support assembly to measure seal drag loads over each hot sliding cycle. The seal drag loads are important for engine designers for structural design considerations of the adjacent engine walls and for sizing panel actuation systems.

The load cells are mounted between two pairs of linear bearings (Fig. 5) so that none of the off-axis loads caused by the connecting rod are transmitted to the load cells. These off-axis loads would lead to inaccuracies in the load readings. To prevent thermal damage of the load cells, cooling air is purged over them. The nominal operating temperature for the load cells is $70^{\circ} \mathrm{C}\left(160^{\circ} \mathrm{F}\right)$, well below their $200^{\circ} \mathrm{C} \quad(400 \%)$ temperature compensation rating. Seal friction coefficients are evaluated by dividing the seal drag load by the normal load applied by the lateral preload system. 
$\underline{T e s t}$ Condition Measurement

Leakage Measurement: Leakage rates are measured upstream of the in-line heaters. Leakage is measured in this manner for several reasons. Measuring the mass flow prior to heating to $815^{\circ} \mathrm{C}$ $(1500 \%)$ precludes the need to cool the gas before measuring it with room temperature flowmeters. Eliminating the need to capture the leaked gas and then cool it saves considerable expense and complexity. Measuring the leakage flow upstream of the seal also gives a conservative estimate of the actual seal leakage rate. The leakage rate that is measured includes both the seal leakage and any minor parasitic leakage mentioned earlier. Three flow meters (Teledyne Hastings HFM-201) are arranged in parallel in a flow bench and are switch-selectable to measure air flows in the following ranges: $0-0.009 \mathrm{~kg} / \mathrm{s}, 0-0.018 \mathrm{~kg} / \mathrm{s}, 0$ - $0.036 \mathrm{~kg} / \mathrm{s}$ ( $0-0.02 \mathrm{lb} / \mathrm{sec}, 0.04 \mathrm{lb} / \mathrm{sec}, 0.08$ $\mathrm{lb} / \mathrm{sec})$.

Pressure Measurement: The pressure differential applied across the seal is evaluated using static pressure taps immediately upstream of the seal. Gage pressure measurements are used since the seal vents to atmospheric conditions and the exiting flow velocities are low. The pressures are measured using solid-state capacitance type transducers. Pressure is supplied to the transducers using suitably long (over $15 \mathrm{~cm}$ ) tubing, to prevent high temperatures from reaching the transducer. Measurements are taken at multiple axial stations so that an accurate average pressure differential is obtained.

Pressures are also measured in the seal cavity behind the seal to determine fluid forces exerted by the chamber pressure. Pressure supplied to the lateral preload bellows is also measured, from which the seal contact stress is calculated.

Temperature Measurement: The temperature of the gas impinging on the seal is measured using fast-acting thermocouples just upstream of the seal. The thermocouple beads are inserted in the gas stream to measure true gas temperature. For averaging purposes, multiple thermocouples are used along the length of each of the $30 \mathrm{~cm}(1 \mathrm{ft})$ seals. Thermocouples are placed at the exhaust of the air heaters and on the surface heaters to monitor temperature and provide feedback signals for the respective controllers.

In all cases, type $\mathrm{K}$ (Chromel-Alumel; $1090^{\circ} \mathrm{C}$ ) thermocouples are used. Wherever thermocouples or static pressure taps are inserted into the pressurized rig, special high temperature fittings are used to prevent parasitic leakage. These fittings are made by Conax Co. and use a proprietary fitting design with magnesium-oxide (lava) type glands capable of $982^{\circ} \mathrm{C}\left(1800^{\circ} \mathrm{F}\right)$ operation.

All sensors are continuously monitored with a PC-based data acquisition system. The host platform is a 486 PC with a LabMaster analog-todigital converter board. Lab Tech Notebook XE software is used to record and display the data.

Seal Preload and Measurement: An important parameter requiring investigation is the seal preload required to adequately seal the pressurized gas. Both lateral preload (i.e., transverse to the seal axis) and axial preload (i.e. rub-block) are measured in the rig. Lateral preload is applied using a series of welded-leaf, flexible Inconel 718 metal bellows (Fig. 4). These $1.3 \mathrm{~cm}$ (0.5 in) diameter bellows are mounted on $2.5 \mathrm{~cm}$ (1 in) centers and are pressurized from a common manifold. In-line with each of the bellows pressure supply tubes is a hand valve that can be used to select the number of active bellows.

A thin (.15 cm (0.06 in)) strip of Inconel is placed between the nose of the sealed bellows and the back of the candidate seal. This strip distributes the preload to portions of the seal between two adjacent bellows. An average seal contact pressure is determined by pro-rating bellows pressure (as measured in the manifold supply) by the ratio of the bellows area to the backside seal area. If all of the bellows are active the average contact pressure is the bellows supply pressure divided by 6.5 .

Fixed Preload: In certain areas of the engine, replacing the "active" preload system with a fixed preload is desirable if seal performance does not suffer. To evaluate the effect of a fixed preload on leakage and durability, the bellows preload system described previously is replaced with a crush bar that is placed behind the seal. These crush bars are installed with shims to effect the proper initial percent crush on the seal. Early durability studies [4] showed the drop off in seal preload with cycling in a fixed preload set-up, but could not measure leakage. The current fixture will enable leakage measurement over the course of seal cycling to determine acceptability of seal flow performance. 


\section{Gap/Wall Conditions}

Uniform Gaps: The seals must seal several different gap conditions at various locations in the engine. The gap in the test zone (Fig. 4) is changed by selecting different saber thicknesses. The thicker the saber the smaller the gap presented to the seal. Gaps that can be tested for the $2.5 \mathrm{~cm}(0.5 \mathrm{in})$ seals are $.07 \mathrm{~cm}$ and .18 $\mathrm{cm}$ (0.03 in and $0.07 \mathrm{in}$ ).

Distorted Gaps: To test seals against wall distortions, the flat saber is replaced with one with a pre-machined surface simulating the engine wall distortion. Sabers with both inward and outward bulges have been designed that replicate the engine wall distortion on an inch per inch-of-span basis.

Surface Condition: Seal friction and wear characteristics can also be assessed against different engine wall materials or surface roughness conditions. This is accomplished by replacing the saber plate with sabers made of any of the candidate engine materials with anticipated engine wall surface roughnesses.

\section{Design for High Temperature Service}

Designing test fixtures for elevated temperature operation requires attention to be paid to certain design elements not often required for conventional design. For instance the rig must be properly sized to meet safety criteria of high temperature pressure vessels. Also allowances must be made for the significant growths that will occur as the fixture heats to the operating temperatures.

Stress Analysis: In sizing the test fixture, a finite element stress analysis of the test rig was performed. The loads used in the finite element model included a $690 \mathrm{kPa}$ (100 psi) seal preload pressure bearing against the front wall, and a 690 $\mathrm{kPa}(100 \mathrm{psi})$ simulated engine pressure applied to the "wetted" surfaces upstream of the test seal. These represent the maximum engine pressure and seal preload envisioned for the test sequence. A vertical force of $568 \mathrm{~kg}(1250 \mathrm{lb})$ was imposed on the top surface of the seal channel representing a maximum anticipated seal drag load. The maximum Von Mises stress found using the MARC finite element code was $39 \mathrm{MPa}(5700 \mathrm{psi})$ at the bottom of the plenum pocket machined into the fixture.

The stress found above was compared to the allowable strength as recommended by the ASME
Boiler and Pressure Vessel Code. In [5] and [6], the design stress is the lesser of one-third the tensile strength at operating temperature or twothirds the yield strength at operating temperature. The first criterion is the more conservative of the two resulting in an allowable design stress of 124 $\mathrm{MPa}$ (18 ksi) (i.e. $1 / 3$ of $372 \mathrm{MPa}$ tensile strength) for Inconel X-750 at $815^{\circ} \mathrm{C}\left(1500^{\circ} \mathrm{F}\right)$ [7]. This allowable stress is significantly greater than the maximum stress calculated for the test fixture. Hence it was concluded that the rig was adequately sized. Comparing the design stress to the Von Mises stress, a factor of safety of 3.2 is found.

In addition to having high yield and ultimate strengths at temperature, Inconel X-750 has a very high creep rupture strength. At $815^{\circ} \mathrm{C}\left(1500^{\circ} \mathrm{F}\right)$, its $1000 \mathrm{hr}$ creep rupture strength of $138 \mathrm{MPa}(20$ ksi) [7] ranks with the best of the high temperature metals. By comparison this creep rupture strength is almost four times that of Inconel 600 and five times that of 304 series stainless steel. Inconel X750 was chosen for the high temperature fixture because of these features and its excellent oxidation resistance.

Large-Scale Thermal Growth: Calculations predicted that the $56 \mathrm{~cm}$ (22 in) Inconel fixture heated to the $815^{\circ} \mathrm{C}\left(1500^{\circ} \mathrm{F}\right)$. operating temperature would grow more than $0.6 \mathrm{~cm}(0.25$ in). To accommodate thermal growth of this magnitude special features were incorporated into the rig:

Rig Tie-Down: Ignoring thermal growth will normally result in unforgiving hardware failures because the thermal strain energy will be released in one way or another. To allow the rig to grow unimpeded, slotted feet were used on both ends. Light tension on the bolts used to secure the rig to the table allows the rig to expand and contract without binding during a temperature cycle. Vertical loads were reacted through tie-down bolts located on the rig centerline.

Piping Manifold: A flexible piping manifold system was implemented in the rig. The manifold allows the heaters to move axially with the rig growth without placing bending loads and unnecessary stresses on the hot heater pipes. Oversize clearance holes are made in the bench top to allow heater movement. The manifold also allows the pipes to grow axially. 
Axial Preload System: The axial preload system actuates the end rub blocks. The rub blocks seal the leakage path at the ends of the saber. As shown in Fig. 6, the load cells and pneumatic actuators are bracketed to the base of the rig. This guarantees that the load cell reading will not be affected by forces caused by the thermal expansion of the rig.

\section{- Test Fixture Demonstration}

The design features incorporated into the test fixture allows a broad range of candidate engine seal concepts to be tested. The test rig is easily configured to test the ceramic wafer seal and the braided ceramic rope seal.

Seal Specimen: For purposes of demonstrating the high temperature capability of the test rig, the ceramic rope seal depicted in Fig. 3 was installed and tested.

Test Results: Leakage rates for the ceramic rope seal sealing $843^{\circ} \mathrm{C}\left(1550^{\circ} \mathrm{F}\right)$ air are shown versus pressure drop in Fig. 7 after 1200 cycles. In this figure, the hot leakage rates are normalized by the leakage rate before cycling. These results show a reduction in leakage with cycling. Though leakage rates were low, the seal was badly damaged during the test indicating that alternative designs such as the hybrid seals are required to withstand the punishing engine sliding conditions.

\section{Summary}

A hot dynamic test fixture for evaluating the performance of advanced hypersonic engine seals has been installed and successfully checked-out at NASA Lewis Research Center. The test fixture will be used to assess the durability and flow change of candidate seals as a function of simulated engine cycles. The fixture can subject seals to simulated temperatures up to $815^{\circ} \mathrm{C}$ $\left(1550^{\circ} \mathrm{F}\right)$ and pressures up to $690 \mathrm{kPa}(100 \mathrm{psi})$. Furthermore, seal performance in sealing either straight or distorted sidewalls can be measured. The sensitivity of leakage performance to either active or fixed preload can also be evaluated.

\section{Acknowledgements}

The authors acknowledge Mr. Mike Tong for the rig stress analysis, Mr. Frank Jasko for detailed design of the components, and Mr. Richard Tashjian for the test fixture installation.

\section{$\underline{\text { References }}$}

1. Steinetz, B.M.: "Evaluation of an Innovative High Temperature Ceramic Wafer Seal for Hypersonic Engine Applications," NASA TM-105556, 1992.

2. Steinetz, B.M.: "A Test Fixture for Measuring High-Temperature Hypersonic Engine Seal Performance," NASA TM103658, 1990.

3. Steinetz, B.M., et al: "Engine Panel Seals for Hypersonic Engine Applications: High Temperature Assessments and Flow Modelling," NASA TM-105260, 1992.

4. Steinetz, B.M., et al: "High Temperature Dynamic Engine Seal Technology Development," NASA TM-105641, 1992.

5. Boiler and Pressure Vessel Code, Section VIII, Division 1. American Society of Mechanical Engineers (1980).

6. Boiler and Pressure Vessel Code, Section VIII, Division 2. American Society of Mechanical Engineers (1980).

7. Kattus, J.R., "Inconel X-750," Aerospace Structural Metals Handbook, Metals and Ceramics Information Center, Battelle Labs, Columbus, OH, Vol. 4, Article 4105 (1990).

Note: Mention of manufacturers is made only for reference purposes and does not constitute a product endorsement by NASA or the U.S. government. 


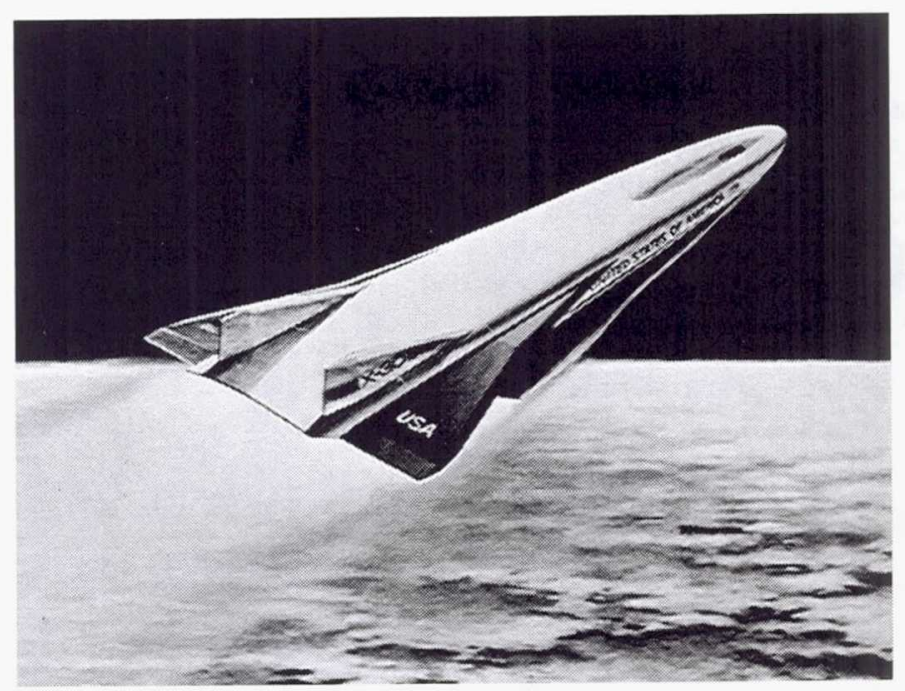

Figure 1: National Aerospace Plane.

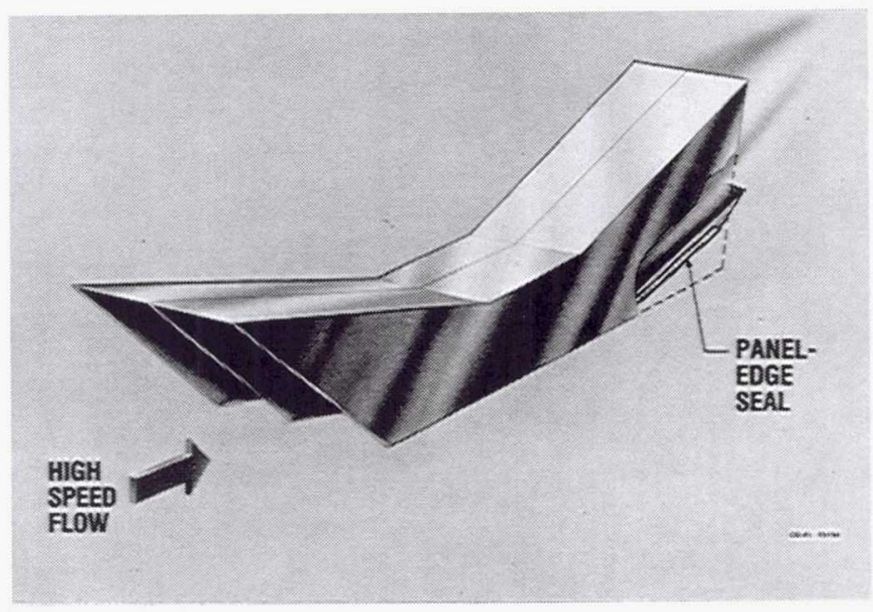

Figure 2: Hypersonic engine panel-edge seal.

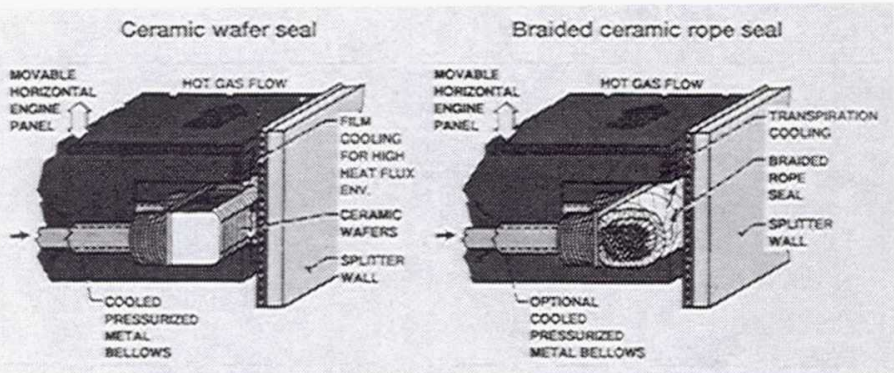

Figure 3: Seal concepts under development. 


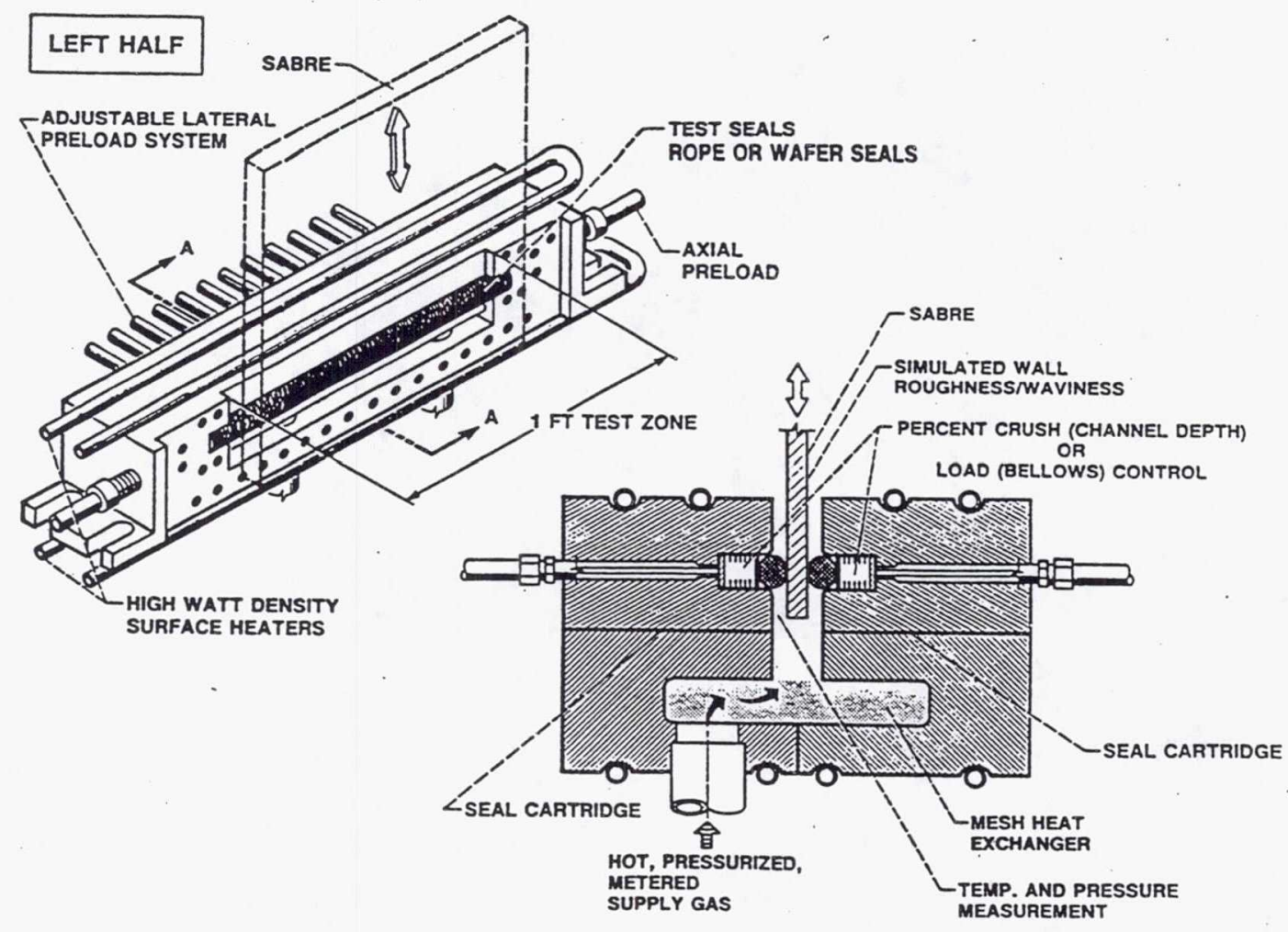

Figure 4: Schematic of seal rig showing the seal holders, hot gas path, and saber motion.

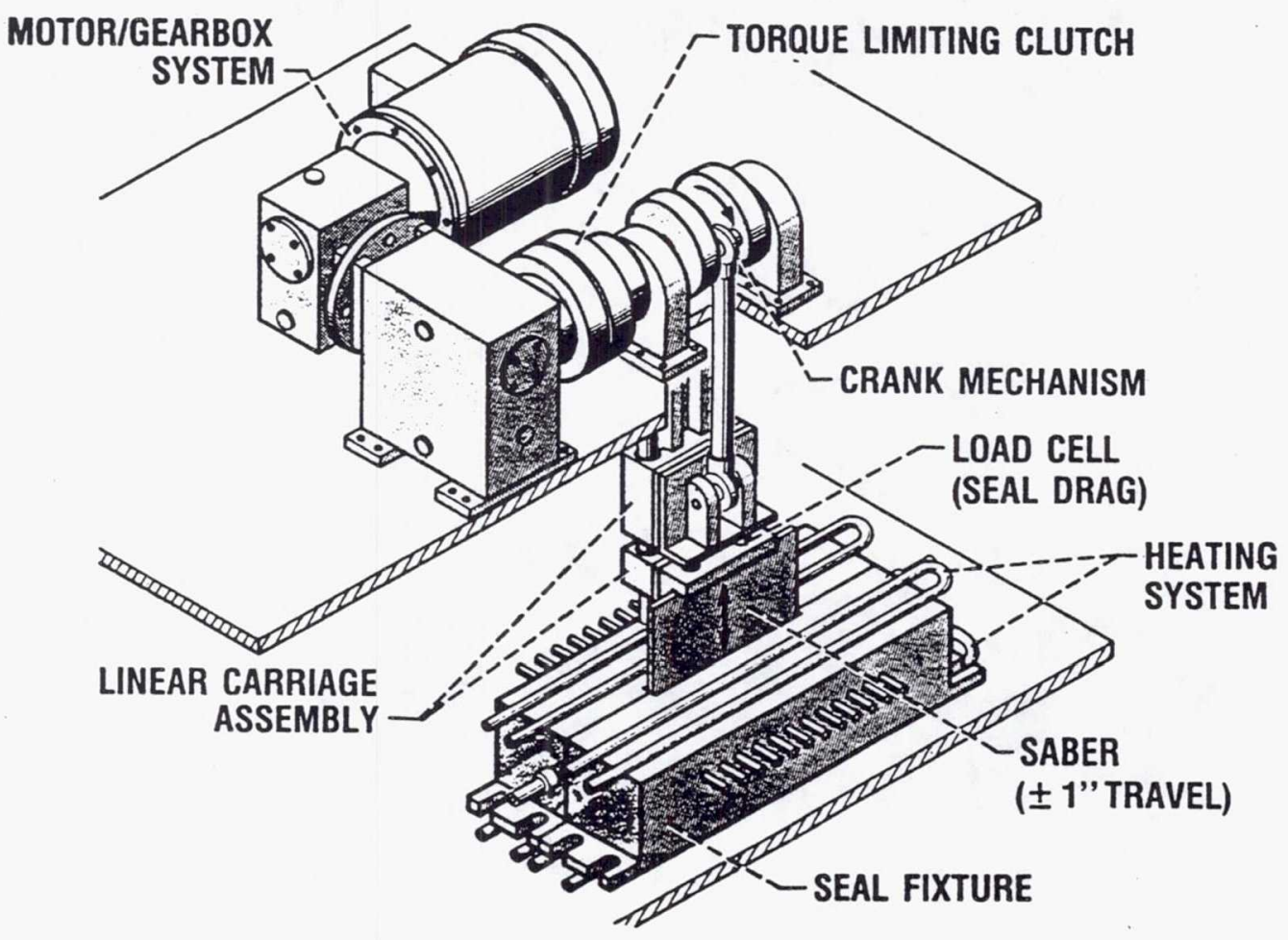

Figure 5: Schematic of actuation system. 


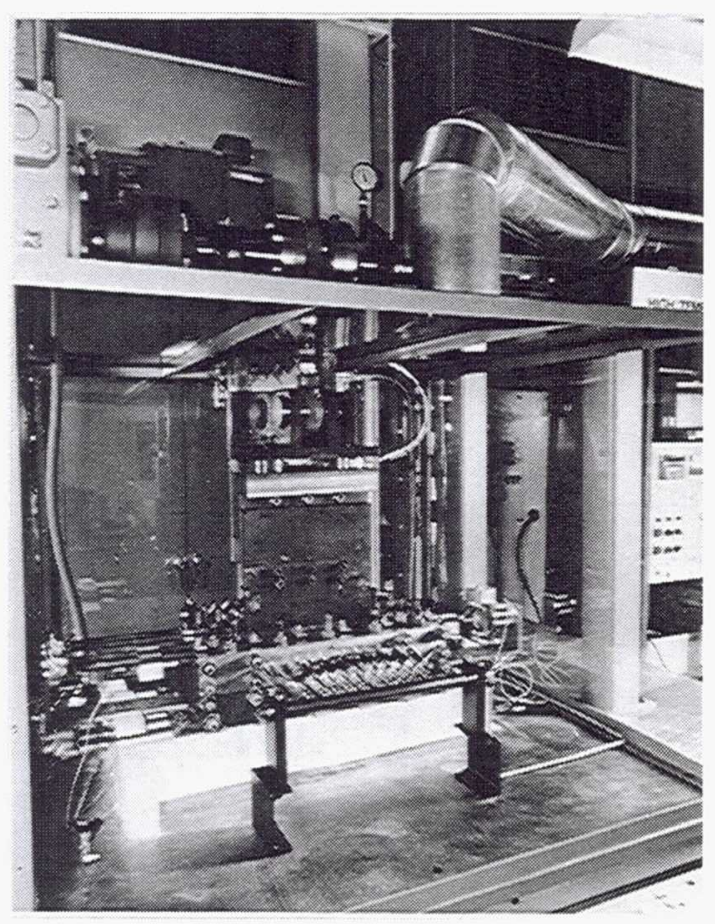

Figure 6: Photograph of high temperature dynamic seal rig.

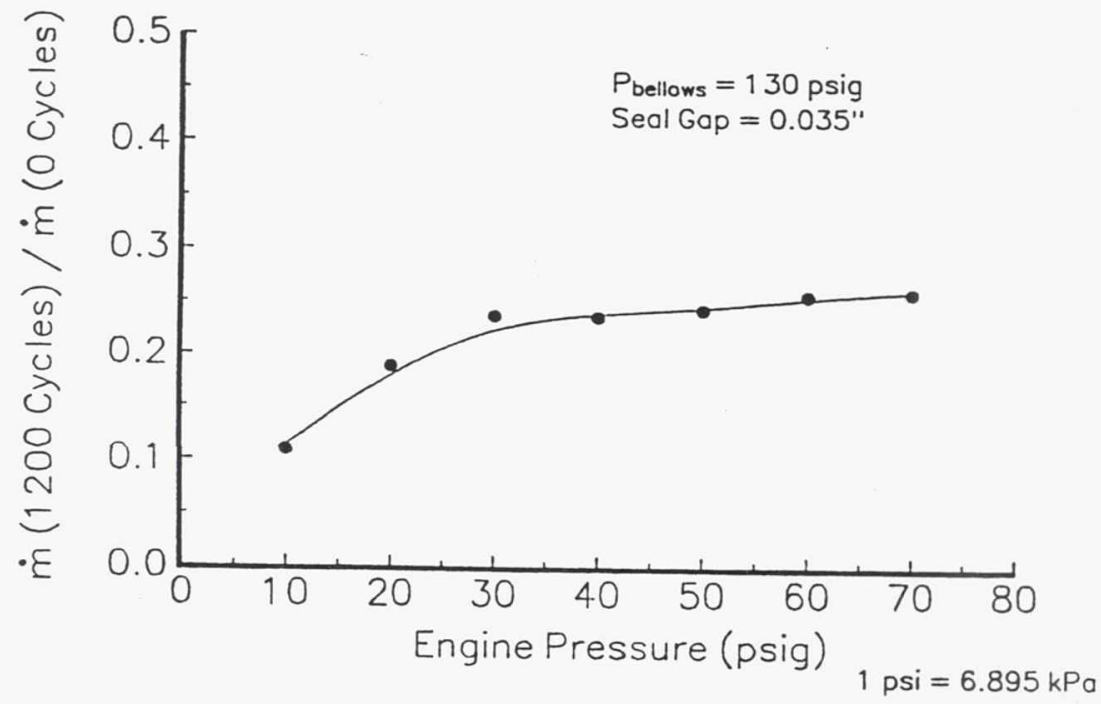

Figure 7: Preliminary data showing high temperature $\left(815^{\circ} \mathrm{C}\left(1550^{\circ} \mathrm{F}\right)\right)$ seal leakage after simulated engine duty cycle showing decrease in seal leakage with cycling. 
Public reporting burden for this collection of information is estimated to average 1 hour per response, including the time for reviewing instructions, searching existing data sources, gathering and maintaining the data needed, and completing and reviewing the collection of information. Send comments regarding this burden estimate or any other aspect of this collection of information, including suggestions for reducing this burden, to Washington Headquarters Services, Directorate for Information Operations and Reports, 1215 Jefferson Davis Highway, Suite 1204, Arlington, VA 22202-4302, and to the Office of Management and Budget, Paperwork Reduction Project (0704-0188), Washington, DC 20503.

\begin{tabular}{|l|r|r|} 
1. AGENCY USE ONLY (Leave blank) & $\begin{array}{r}\text { 2. REPORT DATE } \\
\text { April } 1993\end{array}$ & $\begin{array}{r}\text { 3. REPORT TYPE AND DATES COVERED } \\
\text { Technical Memorandum }\end{array}$
\end{tabular}

4. TITLE AND SUBTITLE 5. FUNDING NUMBERS

A Hot Dynamic Seal Rig for Measuring Hypersonic Engine Seal Durability and Flow Performance

6. AUTHOR(S)

WU-763-22-41

Jeffrey H. Miller, Bruce M. Steinetz, Paul J. Sirocky, and Lawrence A. Kren

7. PERFORMING ORGANIZATION NAME(S) AND ADDRESS(ES)

National Aeronautics and Space Administration

Lewis Research Center

Cleveland, Ohio 44135-3191

9. SPONSORING/MONITORING AGENCY NAME(S) AND ADDRESS(ES)

National Aeronautics and Space Administration

Washington, D.C. 20546-0001
8. PERFORMING ORGANIZATION REPORT NUMBER

E-8031

10. SPONSORING/MONITORING AGENCY REPORT NUMBER

NASA TM-106294

11. SUPPLEMENTARY NOTES

Prepared for the 34th Structures, Structural Dynamics, and Materials Conference cosponsored by the AIAA, ASME, AHS, and ASC, La Jolla, California, April 19-21, 1993. Jeffery H. Miller and Paul J. Sirocky, Sverdrup Technology, Inc., Lewis Research Center Group, 2001 Aerospace

Parkway, Brook Park, Ohio 44142; Bruce M. Steinetz, NASA Lewis Research Center and Lawrence A. Kren, Case Western Reserve University, Cleveland, Ohio 44106. Responsible person, Bruce M. Steinetz, (216) 433-6012.

12a. DISTRIBUTION/AVAILABILITY STATEMENT

12b. DISTRIBUTION CODE

Unclassified-Unlimited

Subject Category 37

13. ABSTRACT (Maximum 200 words)

A test fixture for measuring the dynamic performance of candidate high-temperature engine seal concepts has been installed at NASA Lewis Research Center. The test fixture has been designed to evaluate seal concepts under development for advanced hypersonic engines, such as those being considered for the National Aerospace Plane (NASP). The fixture can measure dynamic seal leakage performance from room temperature up to $840^{\circ} \mathrm{C}\left(1550^{\circ} \mathrm{F}\right)$ and air pressure differentials up to $690 \mathrm{kPa}(100 \mathrm{psi})$. Performance of the seals can be measured while sealing against flat or distorted walls. In the fixture two seals are preloaded against the sides of a $30 \mathrm{~cm}(1 \mathrm{ft})$ long saber that slides transverse to the axis of the seals, simulating the scrubbing motion anticipated in these engines. This report covers the capabilities of this test fixture along with preliminary data showing the dependence of seal leakage performance on high temperature cycling.

14. SUBJECT TERMS

Seal; Experiment; Design; Wear; High-temperature

\begin{tabular}{l|l} 
17. SECURTYY CLASSIFICATION & 18. SECURITY CLASSIFICATION
\end{tabular} OF REPORT

Unclassified OF THIS PAGE

Unclassified
19. SECURITY CLASSIFICATION OF ABSTRACT Unclassified 